\title{
The Cromwellian Protectorate and the Languages of Empire
}

\section{Citation}

Armitage, David. 1992. The Cromwellian Protectorate and the languages of empire. Historical Journal 35(3): 531-555.

\section{Published Version}

http://www.jstor.org/stable/2639629

\section{Permanent link}

http://nrs.harvard.edu/urn-3:HUL.InstRepos:3373617

\section{Terms of Use}

This article was downloaded from Harvard University's DASH repository, and is made available under the terms and conditions applicable to Other Posted Material, as set forth at http:// nrs.harvard.edu/urn-3:HUL.InstRepos:dash.current.terms-of-use\#LAA

\section{Share Your Story}

The Harvard community has made this article openly available.

Please share how this access benefits you. Submit a story.

Accessibility 


\title{
THE GROMWELLIAN PROTEGTORATE AND THE LANGUAGES OF EMPIRE*
}

\author{
DAVID ARMITAGE \\ Emmanuel College, Cambridge
}

\begin{abstract}
A BSTRACT. This article recovers some of the classical, constitutional, and religious languages of empire in early-modern Britain by a consideration of the period between the end of the first AngloDutch war in ${ }_{16} 64$ and the calling of the second Protectoral Parliament in ${ }_{1656} 6$. It examines in particular the strategic and political motivations for Cromwell's 'western design'against the Spanish possessions in the Caribbean and presents the response to the failure of the design and the oppositional literature published around the second Protectoral Parliament as the immediate context for the publication of James Harrington's Oceana $\left({ }_{1} 6_{5} 6\right)$. It is argued that Harrington's Machiavellian meditation on imperialism is intended as a critique of the expansion of the British republic, so placing Harrington more firmly within the oppositional bloc of the late Protectorate. A concluding section details the recovery of this moment of historical argument in the heat of the opposition to Sir Robert Walpole during the early stages of Anglo-Spanish hostility in 17.38-9, and leads to some wider reflections both on the ideological uses of history in the creation of the British empire and on the centrality of the languages of empire to an understanding of Anglo-American intellectual history up to the late eighteenth century.
\end{abstract}

Early in June I655, the exiled earl of Norwich had a dream which he reported to King Charles's secretary of state, Sir Edward Nicholas. The earl, selfdescribed as a 'mad, wild hound', had been known as one of the Court's greatest pranksters, but on this occasion he begged Nicholas to take his vision seriously: 'Laugh at $m e$ if you please, but $I$ cannot forbear to tell you my dream, which my book of Dreames (for I have such a one) expounds, that Cromwell (knowing he hath noe roote by which he should fix where he is, resolves to make himself Emperor of the West Indies, and leave what he cannot keepe to the King ... I have heard a bird sing lately such a kinde of note, which you have liberty to credit as you please, but not to forget $\mathrm{y}^{\mathrm{t}}$ once upon a time I tould you such a Tale'. 'This royalist vision of the translatio imperii may have been absurd, but it was not unexampled among Cromwell's friends and foes. A few days before, back in England, Edmund Waller had published his 'Panegyric to my Lord Protector' in which he called England 'The seat of Empire', and compared

* Earlier versions of this paper were presented at Princeton University and the Folger Shakespeare Library. For comments and encouragement, I am most grateful to Linda Colley, Kate Elliot, Karen Kupperman, John Pocock, David Quint, Theodore Rabb, Quentin Skinner, Lawrence Stone, Dror Wahrman, and Anthony Whyte. I am also grateful to the Commonwealth Fund of New York and the Folger Shakespeare Library for financial support.

1 The Nicholas papers, II: Jan., I653- June, I655, ed. George F. Warner (Camden Soc. n.s. L (London, I 892)), p. 324 (earl of Norwich to Sir Edward Nicholas, 4 June I655). 
Cromwell to an Augustus whose ample embrace had calmed a torn country. ${ }^{2}$ That same week, in Essex, Ralph Josselin heard again a rumour that had been circulating the summer before that Cromwell would be voted the title of emperor by parliament ${ }^{3}$ writing in May I654, Edward Hyde thought the proposed title would be 'Oliverus Maximus, Insularum Britannicarum Imperator Augustus'. ' John Thurloe's man in Cologne reported in September of that year that Cromwell had indeed been dubbed 'Oliver, the first emperor of Greate Britaine, and the isles thereunto belonging, allways Caesar, etc.' . Cromwell's supposed imperial ambitions were explained by the French ambassador to Elizabeth of Bohemia as an effort to arrogate unlimited legislative power to the Protector, 'since the Kings have tied themselfs to keep the laws'. (She was later informed that the army had vetoed the change of style.) ${ }^{6}$ Elizabeth's father's own attempt to become the emperor of a united Great Britain was not too far in the past to be forgotten, even if it was Cromwell who had achieved by force what the Stuarts had been unable to do by contiguity of territory and commonality of crowns. ${ }^{7}$

Yet the imperialism of the English republic may deserve more attention as a republican fear than as a royalist smear. For the royalists, Cromwellian imperialism implied a status above the law and sole legislative power for its emperor, whose personal position might be divorced from the claims of his subjects. For classical republicans, however, the claim to imperial power may have inspired a fear of the conventional Roman typology, wherein empire represents the vicious declension from republican virtue into hereditary monarchy, with citizens transformed into subjects, and the state driven into attenuating expansionism and ultimate collapse. The lack of a full account of the republican-indeed, as we shall see, Machiavellian-moment in the history of Britain's empire is paralleled by the failure to take seriously the imperial monarchy of Oliver Cromwell. Both seem to play upon the incompatibility of republicanism and imperialism, whereby each ideology

${ }^{2}$ Edmund Waller, A panegyric to my Lord Protector (London, I655) (Thomason tracts, BL E84I.2; dated by Thomason 31 May I655), pp. 2, Io.

3 The diary of Ralph Josselin ${ }_{1} 6_{I} 6-168_{3}$, ed. Alan Macfarlane (London, I976), p. 347 (30 May I655); cf. pp. 32 I (2 April I654), 330 (I Sept. I654); cf. An honest discourse between three neighbours touching the present government in the three kingdoms (London, I655) (E840.10; 28 May I655), p. 8: 'there hath been an old Prophecie of [Cromwell], that he should proceed to be Emperour of the North of Europe...'.

${ }^{4}$ Calendar of Clarendon state papers, in : 1649-1654, ed. W. Dunn Macray and H. O. Coxe (Oxford, I 899), p. 359, Hyde to Bellings, 29 May i654; cf. Diary of Sir Archibald Johnston of Wariston, II: I650-1654, ed. David Hay Fleming (Edinburgh, I919), pp. 268 (12 June I654), 273 (20 June I654).

${ }_{5}$ A collection of the state papers of John Thurloe, esq., ed. Thomas Birch (7 vols., London, I 742) (hereafter, TSP), II, 6I4, letter to Thurloe from Cologne, 29 Sept. I654; cf. Calendar of Clarendon state papers, II, 389 (Hyde to Kent, 2 Sept. I654) and Nicholas papers, II, 82 (Patrick Drummond to Nicholas, 8 Sept. 1654).

6 'Unpublished Letters from the Queen of Bohemia, Daughter of James I to Sir Edward Nicholas', ed. John Evans, Archeologia, xxvir (London, I857), 229, 23 I (Elizabeth to Sir Edward Nicholas, 5 July i 655 ).

${ }^{7}$ On the Jacobean vision of the empire of Great Britain, see especially S. T. Bindoff, 'The Stuarts and their style', English Historical Review, Lx (1945), I92-2 16. 
apparently presents to the other a threat of instability and the potential for dissolution. This paper will attempt to substantiate the claims that this republican moment must be recalled from the fit of absence of mind in which historians have lost it; that the competitive claims of republics and empires are central to early-modern political discourse ${ }^{8}$ and that the intellectual history of Britain must attend to the languages of empire as keenly as to the words of republicanism which have effectively drowned them out.

If, as Caroline Robbins noted. 'There cannot be discerned a typical republican imperial ideology, ${ }^{9}$ this may be because no self-reflecting earlymodern empire could accommodate unthreatened a republican ideology, nor could a republic endow itself with an imperial identity without danger to the independent authority of its citizenry. ${ }^{10}$ However, the search for typicality itself is as chimerical and misleading as the wider quest for stable concepts in political discourse. Rather, one should seek moments of argument as the context for utterances; an intellectual history of the British empire, for example, would thus become a narrative history of usage in time. My argument will attempt to illuminate one scene in that narrative, with the light provided by the aetiological recourse made to the republican moment by the 'patriot' opposition to Walpole, and by the ideological uses found for the legacy of that moment during another crisis within greater Britain in the I 770 , when the nascent republican empire of the United States dissociated itself from the domineering imperial republic of the United Kingdom. ${ }^{11}$

The imperial moment of the English republic extends from the peace settlement which concluded the first Anglo-Dutch War in I654 to the second Protectoral Parliament of 1656 , and it comprehends Cromwell's Western Design, the beginnings of the Anglo-Spanish War, the growing opposition to Protectoral rule culminating in the exclusion of members from the ${ }_{1} 6{ }_{5} 6$ parliament, and the publication of Harrington's Oceana. The republic's claim to the British empire went back to the origins of the Dutch War, and was pressed by the accommodation of a royalist treatise to commonwealth ends. John Selden's Mare clausum was originally written in 1618 at the request of

${ }^{8}$ Such claims decisively inform J. G. A. Pocock, The Machiavellian moment (Princeton, 1975) and Quentin Skinner, The foundations of modern political thought, I: The Renaissance (Cambridge, I978), to both of which I am indebted. See also Pocock's 'States, republics, and empires: the American founding in early modern perspective' in Conceptual change and the constitution, ed. Terence Ball and J. G. A. Pocock (Lawrence, Kan., I988), pp. 66-73.

${ }^{9}$ Caroline Robbins (ed.), Two English republican tracts (Cambridge, r969), p. 43. See also Robbins, "The "excellent use" of colonies: a note on Walter Moyle's justification of Roman colonies, ca. i699', William and Mary Quarterly, xxirI (1966), 620-6.

10 The collision of republics and empire is the starting-point for Skinner, Foundations; on 'passive' imperial versus 'active' republican citizenship, see Michael Walzer, 'Citizenship', in Political innovation and conceptual change, ed. Terence Ball, James Farr, and Russell L. Hanson (Cambridge, I989), pp. 2 I I-I 9 .

11 This paper is accordingly meant as a detail from a larger portrait of the ideological origins of the British empire on which I am engaged. 
James I to defend the English crown's sovereignty over the North Sea and the North Atlantic, as a reply to the arguments of Hugo Grotius's Mare liberum. Selden revised the piece at Charles I's and Laud's request in I635 as a response to further Dutch infringements on English fishing rights, and a Latin version appeared the same year. It was not translated into English until parliament called upon Marchamont Nedham to defend the English commonwealth's rights against the 'ungrateful Republick' of the Dutch in i652. Nedham omitted the work's original dedication to Charles, and instead submitted it to parliament as 'its proper Patrons, conceiving it ought to bee no less under your protection than the Sea it self'. The argument, as he summarized it, was that 'the sovereignty of the seas flowing about this island hath, in all times... under every Revolution, down to the present Age, been held and acknowledged by all the world, as an inseparable appendant of the British Empire'. In this sense, the British empire was the area in which Britain's rulers might exercise their authority or imperium, 'forasmuch as the Seas as well as the Isles, passed alwaies into the Dominion of them that have born Rule within this Nation' ${ }^{12}$ While the text itself portrayed the British empire as static and defensive, the frontispiece of this edition showed the English republic ('Angliæ Respub.') as Minerva/Britannia, the emblems of the three kingdoms held under Cromwell's British rule at her feet, with Nepture exhorting her to extend her imperium, 'For Sea-Dominion may as well bee gain'd,/ By new acquests as by descent maintain'd '. ${ }^{13}$ This was the first time the image of Britannia had been used in the context of extending British dominion and, though the origins of this embodiment of expansionism should surprise no-one familiar with the radical strains in later British patriotism, the knowledge of this republican Britannia seems to have been lost along with the Cromwellian moment itself. ${ }^{14}$ Nedham's translation was replaced in its turn by the publication of James Howell's version of the work in I663, which restored the dedication to Charles, with its assertion that 'the British Ocean hath been counted into the royal patrimony of your British Empire', and warned readers that Nedham had foisted the translation upon them 'in the name of a Commonwealth, instead of the kings of England'. ${ }^{15}$ Samuel Pepys, for one, went to Robert Walton's

12 John Selden (trans. Marchamont Nedham), Of the dominion, or ownership of the sea (London, I6 $\left.65^{2}\right)$, sig. a2r, b[I] r, b2r, p. 204. In May i654, rumour in Paris attributed Cromwell's desire to be "called emperor of the seas occidentalis ... an old pretension of the kings that were heretofore of England' to Mare clausum (TSP, II, 287 : letter of intelligence from Paris, 27 May i6 54 ).

${ }_{13}$ Ibid. 'Neptune to the common-wealth of England', unsigned page opposite frontispiece.

14 The frontispiece was designed by Francis Cleyn and engraved by Pierre Lombart (on whom see Sidney Colvin, Early engraving and engravers in England (1545-1695) (London, 1905), pp. 133-5 and Alfred Forbes Johnson, A catalogue of engraved and etched title-pages down to the death of William Faithorne, I69I (Oxford, I934), p. 36), and it was re-used in Thomas Violet, Proposals humbly presented to his highness Oliver... (London, I $_{5} 6$ ). It is not mentioned by Madge Dresser, 'Britannia', in Raphael Samuel (ed.), Patriotism (3 vols., London, i 989), in: National fictions, pp. 27-49. On radical patriotism, see Hugh Cunningham. 'The language of patriotism' and Linda Colley, 'Radical patriotism in eighteenth-century England', in Samuel (ed.), Patriotism, I: the making and unmaking of British national identity, pp. 57-89 and i69-87.

${ }^{15}$ John Selden ('now perfected and restored by' James Howell), Mare clausum; the right and dominion of the sea in two books (London, I663), sig. a[I] r, 'Advertisement'. 
bookstall in St Paul's churchyard as soon as this royalist recension appeared, 'to cause the title of my English Mare clausum to be changed and the new title, dedicated to the King, to be put to it, because I am ashamed to have the other seen dedicate[d] to the Commonwealth' ${ }^{16}$ Thus the traces of the republican moment were decisively effaced in the name of royal imperium, and Britannia was dropped as a republican embarrassment until she first appeared on royal coinage in 1665 .

Yet, if the crown's British empire had been defined as a stable and defensive unit, it was apparent from Neptune's exhortation that gaining 'new acquests' was a viable alternative to hereditary maintenance. This was not merely a poetaster's idle epigram. The English crown had been slow to take up the imperial gauntlet and had proceeded by colonies planted under charter by private individuals and companies. The Navigation Ordinance of $\mathrm{I}_{5} \mathrm{I}$ tied Britain and its overseas possessions for the first time into a single transatlantic trading unit, as allegiance to the crown had been dissolved, and the central government disencumbered of dynastic and historic obligations. The turn to a non-dynastic foreign policy, which could repudiate past alliances and be propelled by economic or religious motives, left the commonwealth and Protectorate open to take an aggressive attitude towards the dominions of competing powers. In November $\mathrm{I}_{53}$, a few months before the Treaty of Westminster which ended the First Dutch War, Anthony Nicholl wrote from Cornwall to Colonel Robert Bennet who was then sitting as a member of the Nominated Assembly in London, 'you Cannott ymagine what great satisfaction itt gives generally to the Country the very discourse of a peace with the Hollander: an absolute settlement with that nation will be of great advantage to this common wealth; for amity with that people would make those two common wealths intire masters of the whole ocean; and you might soe dispose of the trade of the whole world, as you please and where you please ... ytt twere easily to be demonstrated how that the whole profitte of the kings of Spaynes West Indys might be broughte to England and Holland... The advantages are apparent every way' ${ }^{17}$ There was indeed great rejoicing at the news of the peace with Holland when it was proclaimed in April I654, and though the Venetian secretary noted that Cromwell did not personally benefit, the Protector nevertheless 'considered his position strengthened by this treaty, and it is reported he will now assume another title and... style himself Emperor of Great Britain'. ${ }^{18}$

Anthony Nicholl proved a better guide than Lorenzo Paulucci to the options which the Anglo-Dutch peace had provided for Cromwell. The articles of peace were ratified by the Protector's council of state on ig April I654, and we have Edward Montagu's testimony that the council's thoughts

16 The diary of Samuel Pepys, ed. Robert Latham and William Matthews (I I vols., London, I970-83), IV, 205 .

${ }_{17}$ Folger Shakespeare Library, Robert Bennet papers, MS X.d.483 (12), Anthony Nicholl to Robert Bennet, 9 Nov. I653. My thanks to Steven Pincus for this reference.

18 Calendar of State Papers (Venetian), xxix (1653-4), ed. Allen B. Hinds (London, I929), p. 209, Lorenzo Paulucci to Giovanni Sagredo, 8 May i654 (N.S.) 
turned at once in the direction that Nicholl had intimated. A council meeting on the next day apparently discussed plans for a strike against Spain's American possessions, soon to be called 'the Western design' ${ }^{19}$ Since the government had ' 6 o sayle of shipps well appointed swimminge at sea', it seemed necessary to use them 'in some advantageous designe' rather than lay up valuable forces. Accordingly, with scant regard for past alliances or historic antagonisms, the discussion turned on whether to attack France or Spain. Spain seemed the more viable prize, as an enemy to the protestant nation and as the seemingly enfeebled guardian of rich treasure ripe for the picking. Thereby the design could be sold as 'more acceptable to the people of all sorts and the Parliament then any can be'. It also had the advantage of being a potentially limited engagement in the western hemisphere, alongside which it was 'possible, if not reasonable to expect that wee may have peace and trade in Europe'. Cromwell answered the objection that the Dutch might attack after being reinforced by the surplus Spanish trade it would pick up with the curt, 'Deus providebitt', as if he had the assurance of a victorious instrument in a providentially-favoured cause. In the next conversation reconstructed by Montagu, dated two months later in July I654, the Protector again argued providentially for exporting the revolution, 'because we thinke God has not brought us hither where wee are but to consider the worke that wee may doe in the world as well as at home': 'Providence seemed to lead us hither'. Though Major-General Lambert objected that long-distance supply and tropical disease would make the design unworkable, Cromwell brushed aside his objections with the observation, 'Its hoped the designe will quitt cost' ${ }^{20}$ Thus the Elizabethan ideal of a self-financing war was given the assurance of providence to create what would become, to the 'country' ideologues of the next century, the paradigm of a limited colonial and naval war, prosecuted without damage to European trade.

According to John Thurloe, the major stumbling-blocks between England and Spain were the exercise of free trade and religious tolerance in Spanish America. In a post-factum assessment of Protectoral policy drawn up after the restoration, Thurloe told the earl of Clarendon that 'Don Alonso [Cardenas, the Spanish ambassador] was pleased to answere: that to ask a liberty from the inquisition and free sayling in the West Indies, was to ask his master's two eyes'. The Spanish refusal to allow an Englishman to carry his Bible or conduct his business in the New World had been taken as a provocation, and attempts to enforce Spanish law on such matters as acts of aggression. Thurloe

19 These notes are reprinted in The Clarke papers, uI, ed. C. H. Firth (London, Camden Society, I 899), pp. 203-8. Doubt has been cast on their accuracy and veracity by Peter Gaunt who notes that Montagu was not present at the council meeting of 20 July ${ }_{1} 654$, and that the order-books record no meeting on 20 April 1654 : Gaunt, " "The single person's confidants and dependants"? Oliver Cromwell and his protectoral councillors', Historical Journal, xxxII (I989), p. 550, and n. 35. The enterprise was first called 'the Western design' on 5 June ${ }_{16} 64$ (Calendar of state papers (domestic) (1654), p. 20I).

${ }^{20}$ Ibid. pp. 205, 207-8. On Cromwell's providentialism, see Blair Worden, 'Providence and politics in Cromwelliam England', Past and Present, cix (1985), 55-99. 
noted with a dubious sense of legality that Spanish treatment of English subjects showed that Spain and England were already in a state of war and that the western design was thus a riposte and not a first strike. ${ }^{21}$ Thurloe's retrospective apologia may be poor evidence for Protectoral motivations, but it parallels Cromwell's supposed response to Admiral Blake's report of the beating of an English sailor who had insulted a Spanish religious procession. As Gilbert Burnet recounted the incident, Cromwell was moved to the Palmerstonian resolution, 'I will make the name of Englishman to be as much feared as ever was the name of civis Romanus ${ }^{2}{ }^{22}$ This incident is supposed to have occurred in the summer of 1655 , at the same time as rumours of Cromwell's imperial exaltation were at their height on the continent. Burnet's attribution to Cromwell of a quasi-imperial conception of rights of citizenship may be a late example of royalist slander, even if such an imperial identity might have been an unrealised constitutional option for the Protectorate.

Imperialism was not wholly a matter of secular constitutions, however. In the early-modern period, an empire might be endowed with the rights of independent sovereign authority, but it could also be subject to the duties of an eschatological mission. Accordingly, the English commonwealth might have attempted to become 'another Rome in the west', as Milton lamented after its failure, but it had also tried to be a new Jerusalem. ${ }^{23}$ Arthur Williamson has discerned 'one of the impulses which would eventually lead to the later British Empire' in the dream of James Maxwell 'that the land of Luz and Lud, Bethel and Britain, may be united imperially in the person of a prince of Britanish blood', specifically Charles I who, like James and Elizabeth, would be the new Constantine.$^{24}$ One should be generally suspicious of repressed impulses and unachieved desires as implied motors of history, imperial or otherwise, but the millennial urge was notably dormant in that unlikeliest of emperors, Charles. Though Cromwell does not seem to have been endowed with messianic attributes as a direct beneficiary of the millenarianism of the 1650 , with his belief in divine superintendence and the favour of providence, he certainly made for a more apt and active eschatological agent than Charles had been.

In I65 I, John Cotton had apocalyptically identified the expulsion of the Spanish from America as the drying up of the Euphrates predicted in the sixteenth chapter of Revelation, 'that the way of the kings of the east might be prepared' (Rev. I6: I2), and had communicated his reading to Cromwell. ${ }^{25}$

21 TSP, 1, 760-1.

22 Wilbur Gortez Abbott, The writings and speeches of Oliver Cromwell (4 vols., Cambridge, Mass., 1937-47) (hereafter, Abbott), III, 759 .

${ }_{23}$ Milton, The ready and easy way to establish a free commonwealth (1660), in The complete prose works of John Milton, ed. Don M. Wolfe (8 vols., New Haven, 1953-82), viI, 357.

${ }_{24}$ Arthur Williamson, Scottish national consciousness in the age of James VI (Edinburgh, 1979), p. Io6.

${ }^{25}$ Karen Ordahl Kupperman, 'Errand to the Indies: Puritan colonization from Providence Island through the western design', William and Mary Quarterly, xuIv (1988), 91 ; Frank Strong, 'The causes of Cromwell's West Indian expedition', American Historical Review, IV (1899), 239-4I. In I 700, Samuel Sewall interpreted the same passage as foreshadowing the triumph of the Scots 
When Roger Williams wrote to John Winthrop of the still unconfirmed expedition in February I 655, he recalled Cotton's interpretation as one motive behind the design: 'we heare of 6o or an roo Saile. I know the Prot[ector]. had strong Thoughts of Hispaniola and Cuba. Mr Cottons interpreting of Euphrates to be the West Indies: the supply of Gold (to take of Taxes) and the provision of a warmer Diverticulum and Receptaculum then $\mathrm{N}[\mathrm{ew}]$. Engl[and]. is will make a Footing into those parts very precious... ${ }^{26}$ Cromwell made no reference to the millenium in his public pronouncements, though his advisers urged the religious motivation for the design. In a position paper presented to Cromwell in I654, the renegade Dominican Thomas Gage foresaw that a successful attack on the Habsburg possessions would lead to the 'ruining and utter fall of Romish Babylon, and to the conversion of those poore and simple Indians' ${ }^{27}$ The collapse of Babylon and the conversion of the whole of humanity were to be the harbingers of the last age, and in this aspect the western design may have been part of a millennial moment which included the overtures made to re-admit the Jews to England in ${ }_{1655}$, a year widely canvassed as the End of Days, when the Jews would be called and Antichrist cast down. ${ }^{28}$

The amphibious force which had sailed from Portsmouth late in December I 654 was one arm of a double movement against the Spanish, for in October another fleet, under the command of Admiral Blake, had been sent to the Mediterranean to harass Spanish shipping in home waters. ${ }^{29}$ Yet, hastily equipped, and divided in its command, the western fleet under Penn and Venables was to have far less success in its aims, despite the greater hopes that were being placed in it. Though its exact destination was a secret, even to most of those aboard, it had been so long in the making that the design was

Darien expedition: letter of 8 April I 7oo, cit. Thomas Clinton Pears, The design of Darien (n.p., 1936), pp. 79-8o.

${ }_{26}$ The correspondence of Roger Williams, ed. Glenn W. LaFantasie (2 vols., Providence, I988), II, 428. Williams to John Winthrop, ${ }_{5}$ Feb. $1654 / 5$. Williams attributed the news to a ship that had left England four months earlier.

${ }_{27}$ TSP, III, 6I. Gage was sent as a chaplain on the West India expedition of 1655 , and his The English-American his travail by sea and land (London, I648) was republished as $A$ new survey of the WestIndies in the same year, accompanied by an advertisement in Mercurius Politicus (hereafter, MP), 24-31 May 1655, p. 5372.

${ }^{28}$ David S. Katz, Philo-semitism and the readmission of the Fews to England ${ }_{1603}-1655$ (Oxford, I982), ch. 3, 'The calling of the Jews'.

${ }^{29}$ On the western design, see Granville Penn, Memorials of the professional life and times of Sir William Penn (2 vols., London, I833), II, I-I 42 ; A. P. Watts, Une histoire des colonies anglaises aux Antilles (de I649 à I66o) (Paris, I924), chs. 8-13; J. M. Incháustegui Cabral, La gran expedición inglesa contra las Antillas mayores: I, El plan Antillano de Cromwell (Mexico, 1953); S. A. G. Taylor, The western design (Kingston, Jamaica, I959); John F. Battick, 'A new interpretation of Cromwell's western design', Fournal of the Barbados Museum and Historical Society, xxxiv (1972), 76-84; G. M. D. Howat, Stuart and Cromwellian foreign policy (New York, 1974), ch. 7; Charles P. Korr, Cromwell and the new model foreign policy (Berkeley, 1975), ch. I I ; Hans-Christoph Junge, Flottenpolitik und Revolution (Stuttgart, 1980), pp. 247-85; and the articles by Kupperman and Strong cit. n. 25 above. 
'Vulgarly discovered', and rumours had circulated as early as the previous May that its destination was to be Spanish America. ${ }^{30}$ Gilbert Burnet reported long after that 'all were in a gaze whither it was to go: some fancied it was to rob the church of Loretto, which did occasion a fortification to be drawn around it: others talked of Rome itself; for Cromwell's preachers had this often in their mouths, that if it were not for the divisions at home, he would go and sack Babylon...'. No official acknowledgement was made of these plans at home, and 'All he said upon it was, that he sent out the fleet to guard the seas, and restore England to its dominion on that element' ${ }^{31}$ Thus, if Burnet is to be believed, Cromwell's purported aim was the defence of the Seldenian British imperium, rather than the expansion of a British empire.

After stopping to pick up some raggle-taggle reinforcements on Barbados in January 1655 , the fleet continued westward until it reached Hispaniola in the second week of April. ${ }^{32}$ During three weeks on the island, two attempts were made upon the capital, San Domingo. Both failed, and disease and enemy attack killed at least a thousand men. Unused to jungle warfare in extreme heat, the undisciplined army collapsed from lack of food and water, and suffered the rigours of dysentery. Nor could the soldiers fight the enemy on equal terms, because Spanish pikes were two feet longer. These problems of materiel were compounded by the uncertainty bred by the cowardice of the soldiers and the divided command (respect for which was weakened by Venables's attentions to his new bride, for whom the voyage to Hispaniola was an inauspicious honeymoon). Though the commissioners had been charged that the expedition might 'make way for the bringing in the light of the Gospell and power of the true Religion and Godliness into those parts,${ }^{33}$ if God were to be pleased to allow it, Venables protested that instead of six ministers of religion for his forces he had been sent six black clerical coats. ${ }^{34}$ Indeed, the greatest blow for protestantism struck by the forces seems to have been when the "soldiers brought forth a large statue of the Virgin Mary, well

${ }^{30}$ C. H. Firth (ed.), The narrative of General Venables (London, I9oo) (hereafter, Venables, Narrative), p. 5; The letters of Zohn Paige, London merchant, $1648-1658$ (London Record Soc., xxi (London, 1984)), ed. George F. Steckley, p. Iо7; cf. ibid. pp. I 08 , I I 3 , I 16 ; and TSP, II, I52, I54-5, I68-9, $215^{-16}, 267,269,364-5,39^{1-2}, 44^{-15}, 539,59^{2}$ etc. for further rumours about the fleet.

${ }_{31}$ Gilbert Burnet, History of his own time (6 vols., Oxford, I 833), I, I $37-8$.

32 The main contemporary accounts of the design are I.S., A brief and perfect journal of the late proceedings and success of the English army in the West Indies (London, I655) (E853.29; I9 Dec. 1655); B[ritish] L[ibrary] Egerton MS 2648 (Francis Barrington to Sir John Barrington, 6 June 1655 ), rptd. in Historical manuscripts commission, seventh report (London, 1879) (hereafter, $H M C$ ), pp. 57 I-5; BL Add. MS I 2429, fos. $7^{-72}$ and Add. MS I I 4 Io fos. 56-i 43 (copies of Venables's account), Bodleian MS Rawl. D. 208 (five letters on the Design), and BL MS Sloane $39^{2} 6$ (Henry Whistler's journal), all rptd. in Venables, Narrative; and National Maritime Museum, Greenwich, MS Wyn/ro/I, rptd. in John F. Battick (ed.), 'Richard Rooth's Sea Journal of the western design, I654-55', Famaica Journal, 5, 4 (Dec. I97 I), 3-22. For Spanish accounts, see [Francisco Facundo de Carvajal,] Relación de la Vitoria, Que Han Tenido las Armas de Su Magestad ... Contra La Armada Inglesa de Guillermo Pen (Madrid, 1655); The English conquest of Jamaica (Camden Miscellany, xuI (London, 1923)), ed. I. A. Wright, and Spanish narratives of the English attack on Santo Domingo 1655 (Camden Miscellany, xiv (London, I926)), ed. I. A. Wright.

${ }_{33}$ Abbott, iII, $53^{8}$.

${ }^{34}$ Venables, Narrative, p. 6. 
accoutered, and palted her to death with oranges' ${ }^{35}$ The council of state signalled the godliness of the Design with cruel impracticality to an army lacking tents, water-bottles and sufficient food, when on 9 June 1655 it ordered two thousand Bibles to be sent to the soldiers in the West Indies, no news having reached London that God had deserted His troops and that the army had been routed at San Domingo. ${ }^{36}$ After the defeat on Hispaniola, the commanders decided next to 'trust Providence in the attempting of some other Spanish island' and attack Jamaica, which was known to be less well defended. ${ }^{37} 7$ May 1655 was observed as a day of fasting and humiliation on the way to Jamaica, where the chastened forces arrived three days later. ${ }^{38}$ The Spanish there agreed to a treaty without bloodshed, and the British forces spent the next two months mopping up resistance and settling themselves on the island before Penn and Venables sailed back to England, believing their work done in capturing a bridgehead against the Spanish.

The response at home was not to be so sanguine, despite early confidence inspired by misinformation. On 3 April 1655 , the wildest hopes of riches and dominion seemed to have been fulfilled in the report that 'the English are become Masters of no less than three and thirty gold and silver mines, which, if true, will doubtless make our English Continent the most flourishing Common-wealth under the Sun. ${ }^{39}$ Mercurius Politicus carried various notices from across Europe as news filtered back of the fleet's endeavours. Only in July were these accounts finally proved false. ${ }^{40}$ When word reached the Protector on 24 July 1655 , he shut himself alone in his room for a day, and began a long process of self-questioning which was to haunt him to the end of his life. ${ }^{41}$ As Roger Williams related, long afterwards, 'Oliver, in straights and defeats (especially at Hispaniola) desired all to Speake and declare freely what they thought the mind of God was'.$^{42}$ Cromwell, until then assured of divine favour and the friendly eye of providence, could not reconcile his defeat with his sanctioned role. The Swedish ambassador remarked that Cromwell's personal sense of failure was said to have put paid to his plan to take sole legislative

${ }^{35}$ Ibid. App. D, p. I30; cf. App. E, p. I52.

${ }^{36}$ Calendar of state papers (domestic) (1655), p. 204. $\quad{ }^{37} H M C, 7$ th report, p. 573.

${ }^{38}$ I.S., Brief and perfect journal, pp. 19-20; Granville Penn, Memorials of .. Sir William Penn, II, 98.

${ }^{39} \mathrm{~A}$ great and wonderful victory obtained by the English forces, under the command of General Pen and General Venables (London, I655) (E.831.2; 3 April r655), p. 6.

${ }^{40} M P, 7-14$ June 1655 , p. 5404; 2 I-8 June 1655, p. 5436; 28 June - 5 August, r655, p.5452.

${ }^{41}$ Samuel Rawson Gardiner, History of the commonwealth and Protectorate ${ }_{1649-1656}(4$ vols.,

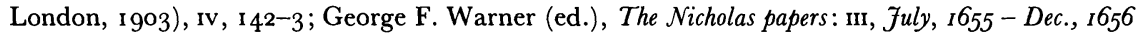
(Camden Soc. n.s. Lvir (London, I897)), p. 30; The life of Mr Robert Blair, ed. Thomas M'Crie (Wodrow Soc., xxm (Edinburgh, I848)), p. 324; Blair Worden, 'Oliver Cromwell and the sin of Achan', in History, society and the churches, ed. Derek Beales and Geoffrey Best (Cambridge, 1985), pp. 125-45. Since both Worden and Kupperman ('Errand to the Indies', pp. 96-9) have dealt with Cromwell's response, I have given more detail on the wider reaction to the failure. It is to be regretted that vol. III of J. M. Incháustegui Cabral's study (n. 29 above), to be entitled Frutos de la victoria y de la Derota, was apparently never written, despite being announced as forthcoming in vol. $\mathrm{I}$.

${ }^{42}$ Correspondence of Roger Williams, II, 704: Williams to John Leverett, II Oct. 1675. 
power to himself, because 'he knows that he urged and insisted on this American adventure singly, against the desire and consent of the whole council, and so can blame no one but himself' ${ }^{43}$ The Protector had felt the blow of the double-edged sword of providence. His language thereafter spoke of 'rebuke' and 'reproof', knowing that he and his people were being cast down in the dust, yet he searched in vain for the cause, and refused to believe that God could have favoured his enemies. Others could find reasons, and the failure of the design became a key point of leverage in opposition to a regime and its leader which seemed to be overstepping itself, both at home (with the rule of the major-generals) and abroad (with its aggressive foreign policy). The response to the western design, among both the self-searching godly and the critical commonwealthmen, was to prove a turning-point for Cromwell as it opened up the question of the godly basis of the republic and the motives for its expansion.

Popular reaction to the news of the defeat was swift and hostile. As one pamphlet sympathetic to the regime noted, 'the Designe now on foot against the Spanjards in the West Indies... is... indeed the discourse of the Nation', ${ }^{44}$ and from Essex to Scotland, from the Welsh borders to the garrison-town of Hull, in the Baptist churches and the Fifth Monarchist conventicles, that discourse was critical and corrosive. ${ }^{45}$ A royalist informant noted that the defeat struck Cromwell 'in point of reputacion with the vulgar in England, who beleeved him invincible, and the souldiery in regard of former success thought themselves soe too'. ${ }^{46}$ That invincibility was laid open to question as the English commonwealth showed itself as vulnerable as any other republic to the caprices of a wilful fortuna, and as God's providential eye seemed to have turned away from his English Israel. Upon their return, both Penn and Venables were locked in the Tower, being taken in (as the Swedish ambassador ominously noted) by the Traitor's Gate. ${ }^{47}$ The Venetian envoy thought that only the wrath of the army stood between the commanders and their execution at Cromwell's orders, and he noted pitifully that the regime

43 Peter Julius Coyet to Charles X, 28 Sept. 1655, in Michael Roberts (trans. and ed.), Swedish diplomats at Cromwell's court 1655-1656 (Camden Society, 4th Series, xxxvi (London, i 988)), i 66-7. Cf. Sagredo, the Venetian ambassador, to the Doge, 28 Sept./8 Oct. I655 (CSP, Venetian (1655-6), p. I I9): 'It is publicly stated that the ill success of the enterprise was due more to the decision to attempt it ... than to irregularities in carrying it out'.

44 A dialogue containing a compendious discourse concerning the present designe in the West-Indies (London, 1655) (Eı1619.2; 20 Sept. 1655), p. 2.

${ }_{45}$ See e.g. The letters and journals of Robert Baillie, A.M., ed. David Laing ( 3 vols., Edinburgh, I842), III, 291, 30 I, 318; Vavasor Powell, $A$ word for God (n.p., i655) (E86r.5; 3 Dec. i655), p. 5; Hypocrisie discovered (n.p., I655), pp. I $3-14$; The picture of a new courtier (E875.6; 18 April 1656) pp. 5, I2; To the honest souldiers of the garrison of Hull (n.p., I656) (669.f.20.31; 25 Sept. 1656), broadsheet, and works examined below. For the Fifth Monarchists' response, see John Canne, The time of the end (London, 1657), p. 88; The old leaven purged out (London, I658), p. 4; Some considerations by way of proposal ... for the ... uniting of all the faithful in this day ( $\mathrm{E}_{74} 6.3 ; 9$ March $\left.{ }_{1} 6{ }_{5} 8\right)$, pp. 2, 7; B. S. Capp, The Fifth Monarchy men (London, I972), pp. I54, I87; and J. R. Jacob, Robert Boyle and the English revolution (New York, 1977), pp. 128-9.

${ }_{46}$ The Nicholas papers, III, $5^{8}$ (Joseph Jane to Sir Edward Nicholas, 24 Sept. I655).

${ }^{47}$ Roberts, Swedish diplomats, p. I66 (28 Sept. I655). 
'declare themselves more determined than ever to prosecute the attempt and to overcome the frown of Fortune by force'.48

By October, Cromwell found himself driven into an officially-declared war with Spain, as his hope for conflict only beyond the line had proved fanciful. This action was defended in a Declaration of His Highness, By the Advice of His Council; Setting Forth...the Fustice of Their Cause Against Spain, which proved the claims of the Spanish to the 'sole Signiory of that New World' to be spurious, and which showed the violations of the jus gentium and jus naturale against both Englishmen in the West Indies, and the natives 'in whose bloud [the Spanish] have founded their Empire', to be egregious and demanding revenge. This was supported by an historical survey which took 'a view of the Transactions between England and Spain and the state they have been in, with Relation to each other, since the Reformation of Religion, and the Discovery of the West Indies; which two great Revolutions, happening neer about the same time, did very much alter the State of Affairs in the world, especially in Relation to the English and Spanish nations'. Cromwell's hope was for a providential defeat of Spain in order that England could replace her as overlord of the Indies, thus running back the clock to link the rediscovery of America with the reformed religion in a restorative ridurre ai principii. Yet even this document registered a doubt about God's purposes while seeming to deny such uncertainty as it concluded with 'the precious opportunities which God hath put into [Englishmen's] hands for his glory, and the advancement of the Kingdom of Christ, which we do not doubt will in the end (all Mists being dispelled and cleered) appear to have been the principall end of the late expedition and understanding against the Spaniard in the West Indies' ${ }^{49}$

The mists showed little sign of clearing. These must have been harrowing days for Cromwell, who had to present the justice of his cause against Spain to excuse the oncoming war at home and abroad, even as he brooded upon God's judgement against his forces six months earlier. As he wrote to Admiral Goodson in Jamaica, 'It is not to be denied but the Lord hath greatly humbled us in that sad loss sustained at Hispaniola; no doubt we have provoked the Lord, and it is good for us to know so, and to be abased for the same... And though $\mathrm{He}$ hath torn us, yet $\mathrm{He}$ will heal us; though $\mathrm{He}$ hath smitten us, yet He will bind us up... The Lord Himself hath a controversy with your enemies, even with that Roman Babylon, of which the Spaniard is the great underpropper. ${ }^{\text {"50 }}$ Still confused by the signals from Heaven and 'the late rebukes We have received', Cromwell ordered a day of solemn fasting and humiliation for 6 December. 'that We may be every one searching out the plague of his own heart'. As Blair Worden and Karen Kupperman have recently shown, the idiom within which the failure of the Design was accommodated was primarily biblical, with the Book of Joshua as the

48 Calendar of state papers, Venetian $\left(16_{55}-6\right)$, p. I 19.

49 Declaration of his Highness, by the advice of his council; setting forth ... the justice of their cause against

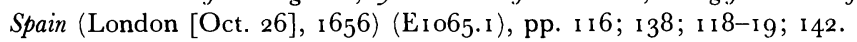

50 Cromwell to Goodson, [3o] Oct. i 655: Abbott, III, 859-6o. 
exemplary typological narrative through which God's judgement upon his People might be discerned. ${ }^{51}$ Though the judgements of providence could be assimilated to those of fortuna, and imperial Rome was as apt an explanatory paradigm for the Protectorate's failures, the main vehicle for opposition and exculpation during these tense months, was the Old Testament story of the sin of Achan.

When news arrived at Earls Colne that the army had been routed in the Caribbean, Ralph Josselin sanguinely remarked in his diary, 'our mouths ful of a great loss at Hispaniola, perhaps it will make the good news that is coming more acceptable, and must rouse us up as Joshua at Ai ${ }^{52}$ In the English Israel, there had apparently been no actual succession from a Moses leading his people to the promised land to a militant Joshua, taking them in conquest against the surrounding foes. This succession had instead been typological, passing not from one man to another, but rather from the image of Cromwell as prophet to his incarnation as general. Before destroying the city of Jericho, Joshua had warned his people, 'keep yourselves from the accursed thing, lest ye make yourselves accursed, when ye take of the accursed thing, and make the camp of Israel a curse and trouble it'. His injunction was ignored by Achan, as he stole a 'goodly Babylonish garment', silver shekels and a gold wedge, and brought down the wrath of the Lord, who allowed the men of $\mathrm{Ai}$ to cow and defeat Joshua's troops, causing them to fly precipitately. As an explanation for the failure at Hispaniola, the story of Achan was distinctly double-edged. While it acknowledged that providence had not censured the design as a whole, or the godliness of its motivation, it implied that some sinful agent had drawn away God's favour: as one defensive pamphlet put it, 'Israel hath sinned, they have medled with the accursed thing: There's the matter. Here was no unlawfulnesse in the design, but unlawfull things done in the managing of it. ... my thoughts tell me it is possible there might be some Achan amongst them ${ }^{53}$ The task, then, was to locate and destroy that Achan if divine favour were to be returned to England under Cromwell, its Joshua. ${ }^{54}$

Or was he its Achan? None could be sure whether the sin of Achan lodged in the nation as a whole, its governors, or the army in the Indies. Cromwell's confusion is shown by his call for another day of fasting and humiliation issued in March of ${ }_{1} 656$. Still unable to fathom the mystery of God's judgement, Cromwell declared, 'The Lord hath been pleased in a wonderful manner to humble and rebuke Us, in that expedition to the West Indies, which although

51 Worden, 'Oliver Cromwell and the sin of Achan'; Kupperman, 'Errand to the Indies', pp. $96-9$.

52 Josselin, Diary, p. 350 (3 Aug. I655).

${ }^{53}$ A dialogue...concerning the present designe in the West Indies, p. 14. The sin of Achan had explanatory and cautionary uses in later British engagements with Spain, e.g. A letter from the commission of the general assembly of the Church of Scotland to the honourable council and inhabitants of the Scots colony of Caledonia in America (Glasgow, I699), p. 4 (the Scots Darien expedition) and [Micaiah Towgood,] Spanish cruelty and injustice a justifiable plea for a vigorous war with Spain (London, I 74 I), pp. 32-3 (the War of Jenkins's Ear).

${ }^{54}$ For Cromwell as Joshua in ${ }^{16} 55^{-6}$, see e.g. George Smith, God's unchangeableness (London, I655) (E824.4; I 5 Jan. I655), p. 4I, and John Phillips (trans.), The tears of the Indians (London, i656) (E $5_{586.1}$; 9 Jan. I656), sig. A4r, and references below. 
we apprehend was not in favour of the Enemy, yet gives Us just reason to fear, that We may have either failed in the spirit and manner wherewith this business hath been undertaken, or that the Lord sees some abomination or accursed thing by which he is provoked thus to appear against Us' ${ }^{55}$ The inclusiveness of the proclamation, and the Protector's conviction that the need for humilitation 'will undoubtedly be agreed by all', presented the defeat as a national crisis in which the government felt that, just as there was silence in heaven, so there was too much speculation on earth, even to laying the blame on the magistrate himself. The news reaching Roger Williams in Providence Plantation was equivocal and disturbing: 'This Divercion against the Spaniad hath turnd the face and thoughts of many English so that the saying of Thouhsands now is Crowne the Protectour with Gould though the sullen yet cry crowne him with thorns ${ }^{56}$ The Protector's self-questioning, and the blame others put upon him for God's controversy with England, made the tragedy of Hispaniola a personal one.

In this context, the Venetian ambassador's report that the collapse of the design prevented Cromwell from taking sole legislative power upon himself coincided with the fears and charges of the godly party. The Declaration of March ${ }_{1} 656$ had implicitly urged the godly to find the Achan in their midst. Sir Henry Vane accepted that challenge in $A$ healing question propounded and resolved upon occasion of the late publique and seasonable call to humiliation and found Achan's sin to be that of self-interest, lodged by implication in Cromwell himself. The opening of Vane's pamphlet took up the language of the Declaration which negotiated the aftermath of Hispaniola. In speaking of a cause that 'hath still the same goodness in it as ever', of the 'blood' and 'treasure' formerly spent in upholding it and of a God who might revive it even when 'secondary instruments and visible means fail', Vane seemed to refer both to the good old cause and to the western design. The failure of the one became a metaphor - or, in more directly theological terms, a sign - for weaknesses in the other. ${ }^{57}$ By observing this signification, Vane was merely unpacking the implications of the Declaration itself. His novel and destructive contribution (for which he was hauled before the council of state, and ultimately imprisoned) was to make this identification explicit. ${ }^{58}$

Vane used the rhetoric of conquest to imply that the evil besetting the government of the three nations was the same as that which followed the Norman Conquest - '[t]he root and bottom on which it stood, was not publique interest, but the private lust and will of the Conquerour'. The result

55 A declaration of his Highness, inviting the people of England to a day of solemn fasting and humiliation (London, [14 March] I656) (669.f.20.25), broadsheet.

${ }^{56}$ Correspondence of Roger Williams, II, 448: Williams to John Winthrop, 2I Feb. I655/6. This is the first hint that the failure of the western design would be connected with the issue of Cromwell's kingship: Worden, 'Oliver Cromwell and the sin of Achan', pp. I4 I-5, argues that the failure of the western design contributed to Cromwell's failure to take the crown.

57 Vane, $A$ healing question (London, I656) (E879.5; I 2 May I656), p. I.

58 ' $\mathrm{H}$. Vane... wrote his discourse entituled A Healing Question but for touching upon (the Noli me tangere) state sins H.V. went prisoner to Carisbrook Castle in the Ile of Wight': Correspondence of Roger Williams, II, 704: Williams to John Leverett, I I Oct. I675. 
of the Conquest had been tyranny; matters looked set fair to go the same way again as power became concentrated in the hands of an oligarchy riding once more on the back of conquest. The regime stood in danger of becoming what it had sought to replace, reviving 'those very Tyrannical principles and Antichristian reliques, which God by us hath punished in our predecessors'. This, indeed, was 'the accursed thing', the sin of Achan, who 'brought not in the fruit and gain of the Conquest unto the Lord's treasury, but covetously went about to convert it to his own propper use... This caused the Lord to kindle against Israel, and made them unable to stand before their enemies, but their hearts melted as water' - just as a cowardly army had shrunk before the Spanish on Hispaniola. Vane made it clear that he had taken up the Declaration's challenge to discover the Achan who had destroyed the design in the Indies by his covert references to weakening before the enemy, to 'dangerous contrivances in forreign parts', and by his final hope that God would break the silence he had kept in heaven for the last three years, 'and become active and powerful in the spirits and hearts of Honest men, and in the works of his providences, when either they goe out to fight by Sea or by Land, or remaine in counsel and debates at home for the publique Weale'. ${ }^{59}$ Though $A$ healing question is usually seen in the context of the dispute among the army, the people and the Protectorate about the direction of the good old cause, its immediate aim was the exposing of Achan, and the healing of the wound made so manifest in the collapse of the western design; its immediate use was to provide a platform on which Fifth Monarchists and commonwealthmen might unite in opposition to a regime whose spiritual bankruptcy had been so clearly revealed in the Caribbean jungles. ${ }^{60}$ In the true spirit of searching humility, it was a retrospective work with an ideological context precisely delineated by the debate on the Hispaniola debacle. Read backwards to the Protector's Declaration and the responses to the western design, rather than forwards to Marchamont Nedham's The excellency of a free state and Harrington's Oceana (for example), A healing question becomes a document negotiating the impact of one debate, rather than simply foreshadowing another.

Yet if the critical strain in the political thought of these years identified Cromwell with Achan, there were also some who could still see him as a Joshua and, once identified with Joshua, as a Caesar or an Augustus. One such was Michael Hawke, whose massively learned, eclectic, and avowedly Hobbesian The right of dominion, and property of liberty appeared in January ${ }_{1} 6_{5} 6$. The work was dedicated to Cromwell as 'Magno, Magnae Britanniae Principi et Protectori, Patri Patriae, et semper Augusto', and its immediate intent was to provide a comprehensive defacto-ist argument for Cromwell's rule and consequently, as its subtitle pointed out, for 'the necessity of his Highness Acceptation of the Empire, averred and approved by Presidents of Præterit

59 A healing question, pp. 4, I4-I 5, 3, 23-4.

60 On the attempted anti-Protectoral alliance sec Capp, Fifth Monarchy men, p. i i 5 ; Jacob, Boyle and the English revolution, p. I 29. The war against Spain, and the Hispaniola defeat, were defended against Vane's strictures in the army pamphlet, A letter from a person in the countrey to his friend in the city: giving his judgment upon a book entituled a healing question (n.p., 1656) (E885.8; 16 Aug. 1656, though dated I 4 June i 656 ), p. 23. 
Ages'. The property of liberty, as Hawke defined it, was complete autarchy, unbounded by the contingencies of necessity, and imitative of God Himself, the freest agent of all. No-one would willingly put themselves under the 'imperious subjection' of another, but in the state of nature Hawke described, 'as Mr Hobbes [says], a sure and irresistible power conferreth the right of dominion and ruling over those that cannot resist'. Thus, 'Dominion ... was first atchieved by valour, and Empires purchased by arms; their creation was by force; though afterwards, some by succession, and others by election, were made Kings'. For Hawke, the assertion of imperium was the general privilege of the victor over the vanquished, while the creation of an empire, with rule by a single person, was the necessary particular remedy for 'ataxy' and 'dissolution' in a commonwealth. As the conqueror of three kingdoms, invested with personal rule by the Instrument of Goverment which had installed him as Protector, Cromwell was 'our Prince, a Caesar for valour, Augustus for fortune, and for prowess and prudence second to neither', who for the exploits of his 'magnanimous Argonautes', Admirals Blake, Monck, and Penn, 'meriteth to be stiled Imperator Oceani', and whom God encouraged as he did Joshua: 'be not afraid nor dismayed, for the Lord thy God is with thee whithersoever thou goest' (Joshua I:I9). De facto, Cromwell's status as conqueror, and his achievements as Protector ensured him the 'empire' of his dominions; nor was this imperial dignity incompatible with the tutelage of the Lord. ${ }^{61}$ Hawke's providentialist imperialism may be one of the strangest progeny of the Leviathan, but it was unique only in the Hobbesian means by which it appropriated familiar classical and religious languages. Once used in opposition to the Protector, these languages were now the guarantors of Cromwell's imperial identity.

The summer of ${ }_{1} 656$ brought a call for the summoning of a new parliament, a year earlier than the provisions of the Instrument of Government demanded. Cromwell was in dire straits, weakened by illness, facing increasing opposition to the major-generals, and still brooding upon Hispaniola. However, he faced the traditional bind of seventeenth-century monarchs, a crisis of supply, and desperately needed parliament to vote him the revenue for the prosecution of a Spanish War under the shadow of a deficit amounting to $£ 800,000$ or $£ 900,000$. Writs for elections were issued in July 1656 , the polls held throughout the three kingdoms in August, and the session opened on 17 September with almost one hundred members either excluded at the door of the parliament-house or failing to turn up. ${ }^{62}$ In the light of the later history of

${ }^{61} \mathrm{M}[\mathrm{ichael}] \mathrm{H}[\mathrm{awke}]$, The right of dominion and property of liberty (London, $\left.16{ }_{5} 6\right)\left(\mathrm{E}_{1} 6{ }_{3} 6 . \mathrm{I} ; \mathrm{i} 6\right.$ Jan. I656), sig. A2r; title-page; pp. 2, 3-4; 4 I ; 50; 83; 86; 89; 90; 93. On Hawke, see Felix Raab, The English face of Machiavelli (London, 1964), pp. I I3, I37, I40-4; Perez Zagorin, A history of political thought in the English revolution (London, I 954), pp. 93-4; Quentin Skinner, 'History and ideology in the English revolution', Historical fournal, viII (1965), i66 and n. 2.

${ }^{62}$ See Paul Jan Pinckney, 'A Cromwellian parliament: the elections and personnel of ${ }_{1} 6_{5} 6$ ' (Unpub. PhD diss., Vanderbilt, I 962), esp. chs. II and viII. 
radical and republican politics, it might be noted that Henry Neville (author of Plato redivivus) was prevented from even being elected in the Reading poll by the intimidation of Protectoral supporters, all of whose five candidates were returned $;^{63}$ and the father of Walter Moyle (author of An essay upon the constitution of the Roman government) was excluded, and signed a pamphlet of protest which complained of Cromwell's 'absolute arbitrary sovereignty' and recalled the challenges to Charles I's call for supply in the ${ }_{1} 628$ parliament. ${ }^{64}$ Anthony Ashley Cooper, later earl of Shaftesbury, also signed this remonstrance, after being debarred from taking up his Wiltshire seat. ${ }^{65}$

Both sides in 1656 , Oliverian and oppositional, appealed to the lessons of the western design, God's judgements upon his nation, and the language of empire, as well as to the more familiar arguments associated with the 'good old cause' with which these languages intersected. 'Who is there amongst us would not clap wings and rejoice to see the Monarchy of this... Nation become vast and Imperial?' demanded one panegyrist, who observed 'we have no little reason to unite and stick close to our Caesar', and lauded him as a Machiavellian 'new prince', ruling over a recently-extended imperium like Ferdinand of Aragon. ${ }^{66}$ On the other side, the widely-distributed election pamphlet England's remembrancers demanded, 'how is the glory and strength of our nation spoiled, and the bloud of many thousands poured forth in wast like water? how is the treasure exhausted, trade and commerce destroyed?' and asked its readers to recall Jamaica as the scene of needless slaughter and loss of English lives. ${ }^{67}$ Again, 'R. G.' in his Copy of a letter from an officer of the army in Ireland, hoped for a 'free Representative' to recompense the godly for their 'faith, prayer [and] expence of bloud and treasure', and alluded to the dark side of Augustanism as he warned that 'neither indeed could any other thing than the just and happy Reign of Augustus Caesar have given the last defeat to the Roman liberty, or made way for those Monsters who succeeded' ${ }^{68}$ while the megalomaniac trimmer and gold-smith, Thomas Violet, called upon Cromwell as 'Pater Patriae' to plunder the Spanish plate fleets and so 'make

${ }^{63}$ Robbins (ed.), Two English republican tracts, pp. 7-8; [Henry Neville?], A true and perfect relation of the manner and proceeding held by the sheriff for the county of Berks at Reading upon the 2oth August (n.p., I656) (E891.8; 20 Aug. I656).

${ }_{64}$ To all the worthy gentlemen who are duely chosen for the parliament which intended to meet at Westminster the 17 of September ${ }_{1} 656$ (n.p., i 656) (E889.8; i 7 Sept. I656), pp. [3], [8].

${ }^{65}$ Ibid. p. [8]; K. H. D. Haley, The first earl of Shaftesbury (Oxford, I968), pp. $9^{\mathrm{I}-2 .}$

${ }_{66}$ The unparalleld monarch (London, 1656 ) (E.675. I ; 22 Sept. 1656), p. 75; sig. A5v; pp, 4, I I. To the author, Cromwell was also 'Moses, Aaron, Foshua, all in one' (sig. [16]v).

${ }^{67}$ England's remembrancers (London, I 656) (E884.5; I Aug. I656), sig. A [ I ]r, A [4]v. Thomason's copy is marked, 'scattered about the streets'; see also Capp. Fifth Monarchy men, p. i 8 , for nationwide distribution.

${ }^{68}$ R. G. [= Richard Goodgroom?], A copy of a letter from an officer of the army in Ireland (n.p., I656) (E88ı.3; 8 June I656), pp. 23, I9. On A copy of a letter, sce J. G. A. Pocock (cd.), The political works of James Harrington (Cambridge, I977) (hereafter, Harrington, Works), pp. I0-1 2; Jonathan Scott, Algernon Sidney and the English republic, 1623-1677 (Cambridge, 1988), pp. I I 5-16. On Cromwell and the 'dark side' of the Augustus myth, sec Howard D. Weinbrot, Augustus Cesar in 'Augustan' England (Princeton, I978), pp. 88-9o, 108. 
your Highness appear the true defender of the faith of these Imperial Dominions' and 'a second Foshua to Israel, to fight the Lord's Battels' whose armed forces were to 'put the People of these Nations in possession of the West-Indies' ${ }^{6}{ }^{69}$

The language of empire and the fall-out of the western design have not been isolated in their relation to the classical republicanism of these years or the specific process and event of the ${ }_{1} 6{ }_{5} 6$ parliament. Yet just that language, and precisely that event, were the matrix for the nodal text of English republicanism, Harrington's Oceana. The parliament was in fractious mood

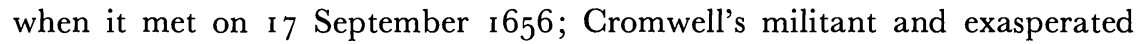
opening speech did little to calm its fears. His business, he said, was 'to speak Things', and in his serious avoidance of mere rhetoric, he identified God's interest in terms of the republic's interest, 'the Concernment of the living people within these three nations, with all the dependency thereupon'. As he put it, succinctly and unreassuringly, "my desire is to let you see the dangers that this nation stands in'. Those dangers came from home and abroad, and Cromwell dilated at length on the threats from cavaliers, levellers, Fifth Monarchy men, papists and Spaniards. He was aware that the two issues causing most disquiet among the members were the Spanish War and the rule of the major-generals. He defended the Spanish War by quoting Genesis 3: 1 5 , 'I will put an enmity between thy seed, and her seed, which goes for little among statesmen, but it is more considerable than all things'. On these grounds, he insisted, 'truly, your great enemy is the Spaniard. He is. He is a naturall Enemy... He is naturally so throughout', not least for his design to gain the empire of the whole world. ${ }^{70}$ Two days after the opening of the parliament, on Friday the i 9 th of September, Livewell Chapman entered 'a book entituled The commonwealth of Oceana, dedicated to His Highness, the Lord Protector ... by James Harrington ' in the Stationers' Register; the work finally appeared in the first week of November. ${ }^{71}$ It has not been remarked before that there may be a causal connection between these two facts, yet Harrington's rush to register his work so soon after the opening of the new parliament indicates that its inception may have given an ideal excuse to those who had been pressing him to publish his book. ${ }^{72}$ It may even be that the textual confusion of the two first editions resulted from Harrington's revision of the work while printing was in progress in order to make his satirical advice on the conduct of the commonwealth more pointedly topical. In this context, Oceana appears as a humanistic text of counsel, not merely generically but operatively, in that an arena was available in the new parliament for its

\footnotetext{
69 Thomas Violet, Proposals humbly presented to his Highness Oliver Lord Protector of England (London, I656), sig. B[I] r, N[I] v, N2v. $\quad{ }^{70}$ Abbott, IV, 260; 26I-2; 264; 269.

${ }^{71}$ A transcript of registers of the Worshipful Company of Stationers; from $1640-1708$ A.D. (3 vols., London, I913), II, 86; $M P, 29$ Oct.-6 Nov. I656, p. 7362 (advertisement for publication).

${ }^{72}$ Though J. G. A. Pocock has noted the timing, he makes no causal connection: Harrington, Works, p. I4. Only V. T. Harlow, The character of British imperialism (London, I939), pp. I5-16, and Richard Koebner, Empire (Cambridge, I961), p. 66, have made any link between the western design and Oceana.
} 
realization, should the members, and most of all the Protector, so choose to use the occasion. As J. G. A. Pocock puts it, 'Harrington's ideal moment is all but immediately present; the whole point of the fiction is that it meant to assert that England/Oceana and Cromwell/Olphaus stand at a point in time at which the ideal work of legislation can actually be performed ${ }^{73}$

Though Pocock has also observed that 'Oceana can have played no part in the parliamentary elections', ${ }^{74}$ it may be rather that any link between parliament and publication runs in the opposite direction, with that ideal legislative moment not 'all but', but in fact, present. Harrington's admission that the Oceana was 'but a rough draught, for I have not been yet two years about it, nor ever saw all or halfe my Papers together'75 implies that its inspiration may have been more immediate than the death of Charles (the 'Preliminaries', at least, can date from no earlier than the summer of ${ }_{16} 66$, since they contain allusions to works published in June of that year), ${ }^{76}$ and that it was composed sectionally rather than linearly, and so was subject to dispersal and revision. The confusing textual states of the first editions seem to confirm such a speculation. In both of the editions of Oceana produced in I 656 , the pagination runs regularly up to page 239 , then the verso of 239 is blank before pagination begins again on 255 and runs to 286, whereupon the pages of the 'Corollary' are numbered 189-2 10. Harrington marked this disjuncture in his errata with the cryptic passage, 'A Mark. - A Mark. - A Mark. - A Spanell questing hath sprung my Book out of one Presse into two other, wherefore you will find the Retrieve, or that which follows next, differently marked from what went before; and the Corollary from this'. ${ }^{77}$ The ruptures before the Lord Archon's speech and the 'Corollary' suggest that each was available for printing as a manuscript on newly-begun sheets; one might infer from this that each was individually, and hence strategically, composed independently of the main body of the text.

The similarities of tone, structure, and argumentative appeal in the summatory speech of the Lord Archon and that of the Protector before the ${ }_{1} 656$ parliament may indicate that the Archon's oration was intended as a Machiavellian recension of Cromwell's words, a warning out to the Protector from his alter ego in the fiction. The Lord Archon begins his speech as if 'haranging at the head of his Army', and unequivocally declares that 'A Government of this Make, is a Commonwealth for increase'. At the opening of the Oceana, Harrington had declared that Britain 'seemeth to have been designed by God for a Common-wealth' like Venice, which was nevertheless

73 Harrington, Works, p. 74 .

74 Ibid. p. I4.

75 James Harrington, The common-wealth of Oceana (London, ${ }_{16} 6$ ) (hereafter, Oceana), sig. [A3]r; Works, p. I 56 .

${ }_{76}$ Oceana, pp. 27, 36; Works, pp. I 85, 193. The works are Thomas Hobbes, Six lessons to the professors of Mathematics (London, I656), dedication dated io June 1656 ; and J.S., Syllogologia, or a historical discourse of parliaments... (London, I656) (E I646. I ; 4 June I656).

77 Oceana, sig. [A4]v; Works, p. 7. For a bibliographical analysis of Oceana's publication, see

$\rightarrow$ John Feather 'The publication of James Harrington's Commonwealth of Oceana', The Library, xxxiI (1977), 262-8. 
constrained by its position and lack of arms to being a Machiavellian commonwealth for preservation, whereas Britain, 'reduced unto the like Government, is a Common-wealth for encrease, and upon the mightiest foundation that any hath been laid from the beginning of the World.... The Sea giveth law unto the growth of Venice, but the growth of Oceana giveth law unto the Sea'. This is the British empire (in Selden's terms) of 1656 , three kingdoms united under a single head with its people masters of the ocean after naval victory over the Dutch. Yet Oceana is an exercise in counterfactuality, albeit a fiction with a potential future. Only when the fictional Britain had been 'reduced unto the like Government' could it become a commonwealth for increase. The thirty 'Orders' proposed before the council of legislators formed the basis of this government, placing it on the basis of a firm agrarian law which would fix the balance in lands and hence stabilize the tillage, the armed citizenry, and the commonwealth itself. Harrington expressed the dependency of each of these provisions on the other in the term 'empire', that is, authority, which he defines as being of 'two kinds, Domestick and National, or Forrain and Provincial'. Harrington's aim was a commonwealth constructed under the rules of ancient prudence, 'an empire of laws and not of men', rather than the defacto-ist's 'empire of men and not of laws'. The decisive break between ancient and modern prudence had occurred with the rule of Julius Caesar; similarly, it was only under the emperors that Rome made the error of planting her citizens beyond the bounds of Italy, creating hostile colonies which demanded liberty. ${ }^{78}$ By implication, the perfect commonwealth is an expanding, but non-imperial, republic, under the rule of law, planting its own people abroad as dependent provincials, and with an extending agrarian which would allow the increase of 'empire' as well as 'dominion', of authority as well as property, by equal and mutually balancing strides.

Yet, as Machiavelli argued, the process of changing a commonwealth for increase into one for preservation could not be forced without the commonwealth destroying itself. All that could impel a commonwealth to do so would be 'necessity': ' ... to many things that reason does not persuade thee, necessity [necessità] binds thee; so that having settled a commonwealth able to maintain itself, not augmenting, and necessity should force it to enlarge itself, it would manifestly loosen its own foundations, and suddenly bring itself to ruin' ${ }^{79}$ Cromwell had appealed to such an aggressive and compulsive necessity in his speech before the parliament as the reason for calling the assembly, demanding supply (the traditional plea, of course) ${ }^{80}$ setting up the

${ }^{78}$ Oceana, p. 255, sig. B2r, p. 4; Works, pp. I59-6o; $163 ; 320$.

79 Discorsi, $\mathrm{I}$, vi: ' ... a molte che la ragione non t'induce, t'induce la necessità; talmente che avendo ordinata una republica atta a mantenersi non ampliando, e la necessità la conducesse a ampliare, si verrebbe a tor via i fondamenti suoi ed a farla rovinare piú tosto' (Niccolò Machiavelli, Opere, ed. Mario Bonfantini (Milan, I 954), p. Io9: my emphasis). Trans. E[dward] $\mathrm{D}$ [acres], Machiavels discourses (London, ${ }_{1} 6{ }_{3} 6$ ), p. 35. For a discussion of this passage, see Pocock, The Machiavellian moment, pp. I97-99.

${ }^{80}$ See especially G. L. Harriss, 'Medieval doctrines in the debates on supply, 16 10-1629', in Faction and parliament, ed. Kevin Sharpe (London, 1985), pp. 73-103, and John Guy, 'The 
system of major-generals, and prosecuting the war against Spain: "we are ready to excuse most of our actions - aye, and justify them as well as excuse them - upon the grounds of necessity; the grounds of necessity being above all considerations of justification and instituted law... events and issues being from God alone, to whom all issues belong, ${ }^{81}$ This insistence upon 'necessity' was the main memory Cromwell's listeners took away from his speech, and it formed an insistent strain in the oppositional literature produced on the occasion of the parliament. ${ }^{82}$ Oceana implies that, under the Protectorate, England is constituted as a commonwealth for preservation, not yet secure enough in its form of government and the balance of its agrarian to expand, safe only in its essential, republican role as master of its external environment, and so Cromwell's appeal to necessity means that it could only be faced with ruin. Harrington's Machiavellian scheme implicitly rules necessity out of court as a motive for the change from a commonwealth for preservation to a commonwealth for expansion, and judges the Protector's plea accordingly.

Cromwell had done little to reassure his audience in September ${ }_{16} 6$ (perhaps he did not yet have that assurance himself) that the enterprise against Spain was still a godly one when he could summon no higher justification than 'necessity'. Yet the Lord Archon's commonwealth for expansion, if it were to imitate Rome and be successful, would have to respect the difference between godly, tutelary 'patronage' and immoral, tyrannical 'empire': 'This is a Commonwealth of the fabrick, that hath an open ear, and a publick concernment. She is not made for herself only, but given as a Magistrate of God unto mankinde, for the vindication of common Right and the law of Nature. Wherefore saith Cicero of the... Romans, (Nos magis patronatum [sc. patrocinium] orbis terrarurm suscepimus, quam Imperium) we have rather undertaken the Patronage than the Empire of the world'. Cicero's conception of empire as untrammeled authoritarian dominion was paralleled by Cromwell's own usage before parliament, when he charged that the Spanish 'design was the empire of the whole Christian world, if not more', ${ }^{83}$ a universal monarchy to which England presented the greatest obstacle. In the light of the distinction between 'patrocinium' and 'imperium', the Archon revised his

"imperial crown" and the liberty of the subject: the English constitution from Magna Carta to the Bill of Rights' (unpublished paper). My thanks to Professor Guy for a copy of this paper.

${ }^{81}$ Abbott, Iv, 26I.

82 An appeale from the court to the country. Made by a member of parliament larefully chosen, but secluded illegally by my Lord Protector (London, I656) (E89r.3; 27 Oct. 1656), p. 5; A narrative of the late parliament (so called) (London, I657) (E935.5; Feb. I658), p. 30; the MS note in the Folger copy of $A$ book of the continuation of forreign passages (London, r657) (Folger B 37 I6), p. 6o: 'All Rebellion proceeds from pretences of Religion and Reformation. Necessity is their sanctuary for sin, which themselves make, endorsing that maxim in Livy, Bellum justum, quibus necessarium. It was anciently the maxim of Rome pagan: and is at the present of the Turks and Dutch, never of the Christians' (referring to the description of the Spanish War as 'just and necessary': the quotation is from Livy, Ix, I, cit. Machiavelli, Principe, xxvi); C. H. Firth, The last years of the Protectorate (2 vols., London, I 909), I, 9-10, n. I.

${ }^{83}$ Abbott, Iv, 262. 
mission for Oceana, and gave an eschatological turn to the idea of empire which has caught commentators on his speech by surprise: 'A Commonwealth ... of this make is a Minister of God upon earth, to the end that the world may be governed with righteousness. For which cause ... the orders last rehearsed are the buds of Empire, such as with the blessing of God, may spread the arms of your Commonwealth, like an holy Asylum unto the distressed world ${ }^{84}$

The presentation of Oceana as a commonwealth for expansion with a godly mission to export liberty and aid oppressed peoples has often been seen as a prophetic vision of British imperialism (most notably by J. A. Froude in his federalist travel narrative of $\mathrm{r} 886$, Oceana or England and her colonies). ${ }^{85} \mathrm{Yet}$, as with all such texts, a retrospective reading is more fully historical than a proleptic one. Though the Lord Archon's speech provided a blueprint for a new Roman empire of patronage, it did so by classical precedent and under the pressure of a contemporary response, and thereby injected a potent critique of empire into the British republican tradition. The speech was intended as a humanistic, republican and above all Machiavellian recension of Cromwell's own speech in the Second Protectoral Parliament. Such a recension explains, at least in part, the textual confusions of Oceana; and more pungently, it places the work as the supreme contemporary text of the imperial moment in the English republic. This is the speech the Protector/Archon should have given before the assembly of England/Oceana; by implication, it was the oration he might yet give if Harrington's other proposals for forming England into a commonwealth for expansion were heeded. Thereby it might be possible to create another Rome in the west, if its lord would only speak in language of republicanism inflected by millenary imperialism.

This imperial republic was not to be achieved by Cromwell, and its premature epitaph was written in Machiavellian language by Richard Hawkins in his Discourse of the national excellencies of England late in I657. Like Harrington, Hawkins believed that England had such a firm territorial basis that it might outdo even 'Rome, the onely Mistress of the World... And if, in our conceits, we should give it answerable growth, we could not assign it less than the whole world at last for its portion'. His verdict was that 'This Commonwealth, how imperfect soever in it self, was too strong in all likelyhood for any humane power or strength to break. It was onely capable of being ruined by God and it self'. Yet it had been debilitated by 'ease and vice' in the aftermath of the first Dutch War, and so was quickly 'dissolved and gone', as God 'undertook this Common-wealth, and laid it in the dust, with those other glorious States of Rome, Athens, Sparta, and Carthage, ${ }^{86}$ a victim of post-republican luxury, and

${ }^{84}$ Oceana, p. 258; Works, p. 323. The quotation paraphrases Cicero, De Officiis, in, 27.

${ }^{85} \mathrm{~J}$. A. Froude, Oceana; or England and her colonies (London, I886), pp. I-4; Judith Shklar, 'Ideology-hunting: the case of James Harrington', Amer. Pol. Sc. Rev., LiII (I959), 677-8; Z. S. Fink, The classical republicans (Evanston, 1962), pp. 188-9; Christopher Hill, The experience of defeat (London, 1984), p. 206.

${ }^{86} \mathrm{R}$ [ichard] $\mathrm{H}$ [awkins], $A$ discourse of the nationall excellencies of England (London, 1657) (EI583.2; 2 I Nov. 1657), pp. 232-3; 234; 235. 
the peculiar fate of the millenial republic, subject both to the Machiavellian fortuna in secular time, and to the vengeful dispensation of providence through the translatio imperii.

\section{I}

The imperial moment of the English republic was recovered in the heat of Walpolean opposition in I 738-9. The War of Jenkins's Ear seemed to many to replay the tensions of the mid-seventeenth century as Spanish guardacostas attacked British shipping in the Caribbean.$^{87}$ This aggression became a rallying-point for the opposition to Walpole, though the government stood firm in its resolution to conciliate and negotiated the Convention of Pardo in 1 738. A flood of propaganda harped on the shame and injustice of this action, and as part of it, the whig canon was expediently augmented by Cromwell's Declaration ... Against Spain, attributed to 'the immortal Milton' ${ }^{88}$ The Spanish refused to ratify the treaty, and Walpole was forced to declare war in October I 739 to the delight of the nation, and the satisfaction of the patriot opposition which looked forward to a limited naval war in the western hemisphere.

The western design was employed as a blueprint for empire in the wake of another amphibious expedition under divided military and naval command in I 74I, when Brigadier-General Thomas Wentworth and Admiral Edward Vernon attacked Cartagena, with apparent success. One author compared the capture of Cartagena to Cromwell's prize of Jamaica, and recalled that 'when Oliver Cromwell was Protector, and had settled his government in 1654 , a laudable ambition carried him so far with honour, as to establish the name of this nation abroad, that he hoped to see it in as much esteem as the Romans ever were. ${ }^{89}$ Yet the comparison should have been with Hispaniola, rather than Jamaica, for news came back soon after that Wentworth's troops had been repulsed with heavy losses. The failure of the western design was recuperated by the attribution of a specifically British and imperial design to Cromwell, which was in turn used to exonerate the wisdom of Wentworth's attack on Cartagena when The Craftsman stated that Cromwell's 'aim was not so piddling as to take St. Domingo, with the island of Hispaniola', but rather he

87 The best account of the origins of the war is Philip Woodfine, 'The Anglo-Spanish War of I739', in Jeremy Black (ed.), The origins of war in early modern Europe (Edinburgh, 1987), pp. I 85-209; see also G. B. Hertz, 'The war fever of 1739 ' in British imperialism in the eighteenth century (London, I908); and Kathleen Wilson, 'Empire, trade, and popular politics in Hanoverian Britain: the case of Admiral Vernon', Past and Present, cxxi (1988), 74-109.

${ }^{88} \mathrm{John}$ Banks, $A$ critical review of the life of Oliver Cromwell (London, i 742), p. 206. Editions include: A manifesto of the Lord Protector ... written in Latin by John Milton... (2 edns, London, 1 738); The British sailor's discovery: or the Spaniard's pretensions confuted (London, I 739), pp. 53-72; A true copy of Cromwell's manifesto against Spain (London, I 74I). It was cited on the front page of The Country journal; or the Craftsman, 25 March I737/38. For the attribution to Milton, see A complete collection of the historical, political, and miscellaneous works of John Milton, ed. Thomas Birch (2 vols., London, I 738), I, xxxiv, and John T. Shawcross, 'A survey of Milton's prose works', in Achievements of the left hand, ed. Michael Lieb and John T. Shawcross (Amherst, r974), pp. 36o-3.

89 The importance of Jamaica to Great Britain consider'd... (London, [I 74I]), p. 2; cf. [Charles Leslie,] A new history of Jamaica (London, i 740), pp. 59-80. 
'had his Eye particularly on Cartagena, which he had intended for the chief seat of the British empire in that Part of the world'. ${ }^{90}$

The lesson of such reconstructions of the past in the service of the ideology of the present was not lost on one opponent of war with Spain, who found in the disjuncture between the I650s and the I730s cause for criticism, not inspiration: 'We have been told too much of our heroic exploits formerly, particularly of Cromwell's Bold Strokes, upon National Provocations', yet Cromwell was the tyrannical wielder of absolute power, 'and he exercised it absolutely, as well as sternly, but rather for himself than for the Publick, both at Home and Abroad, when, to support himself in his Usurpation, he made preposterous wars and weaken'd Spain, already too weak, by joining with France, already too strong. - This he did with his Eyes open, and sacrificed the Interest of his Country, in that Instance too, to his own'. Any appeal to history was thus redundant because 'The Circumstances of 'Times differ'. ${ }^{91}$ Walpole's regime acted on current necessity, the patriot opposition on bygone identity. Both in the Court whigs' resistance to the past, and the patriots' espousal of it, the point was proved that history is always an available resource for ideology, because ideology itself forms and deforms history. Quentin Skinner's conclusion may hold in the case of this imperial moment: "The "whig" ideology indeed obviously amounted neither to genuine history nor to systematic political theory. It was more like political propaganda in historical dress... ${ }^{92}$ The historical dress of empire was in fact the emperor's new clothes.

Yet the emperor had not reckoned with the children who saw his nakedness. The first to proclaim it would be the rebellious inhabitants of British America in the I 770 . John Adams used the legacy of the first British empire's Cromwellian moment when he invoked the authority of Harrington to affirm that beneath the dress of that empire was but a republic, which could have no jurisdiction over its dependencies: 'we are not a part of the British empire; because the British government is not an empire... it is a limited monarchy. If Aristotle, Livy, and Harrington knew what a republic was, the British constitution is much more like a republic. They define a republic to be $a$ government of laws and not of men. If this definition is just, the British constitution is nothing more nor less than a republic, in which the king is first magistrate'. Adams effectively foreclosed the possibility of a British assertion of empire by understanding the term as being solely 'a despotism, and an emperor a despot,

90 The Country journal; or the Craftsman, I I July I 74I (also in The Gentleman's Magazine, I I (I 74I), 366-9; The Daily Gazetteer, I 3 July I 74I ; The London Magazine, I o (I 74I), 34I-4); cf. The conduct of Admiral Vernon examin'd and vindicated (London, I 74I), pp. 2-3.

91 Popular prejudices against the convention and treaty with Spain (London, I 739), pp. 6-7. See also Strenuous motives for an immediate war against Spain (London, I 738), p. I9; [George, Lord Lyttelton,] Farther considerations upon the present state of affairs... in a letter to a minister (London, 1739), p. 24; Ministeral prejudices in favour of the convention, examin'd and answer'd (London, I 739), pp. I5, I6- I 7; Reasons for giving encouragement to the sea-faring people of Great-Britain, in times of peace or war (London, I 739), p. I5, and [John Oldmixon,] The history and life of Robert Blake (London, [1 740]), p.86.

92 Skinner, 'History and ideology in the English revolution', p. I 78. 
bound by no law or imitation, but his own will' ${ }^{93}$ Yet an empire could also be the bearer of a millennial mission, an independent sovereign state, or (as Adams noted) simply 'synonimous with government, rule, or dominion ${ }^{, 94}$ in any of which forms it might not be incompatible with a republic. So, Alexander Hamilton could call the republic arising in post-revolutionary America, 'an empire in many respects the most interesting in the world' ${ }^{95}$ Perhaps it was not after all inevitable that republics and empires should always be irreconcilable; much depended on the languages used to discuss them. It is in this sense that the translation of empire, once a divine prerogative, is now the humbler task of the historian.

${ }_{93}$ John Adams and Jonathan Sewall [sc. Daniel Leonard], Novanglus and Massachusettensis; or political essays (Boston, I8I9), pp. 83-84.

${ }_{94}$ Ibid. p. 84 .

95 James Madison, Alexander Hamilton, and John Jay, The federalist papers, ed. Isaac Kramnick (Harmondsworth, I987), p. 87 (number I, 'Introduction'); the uneasy marriage of 'republic' and 'empire' after the American revolution is the subject of the final chapter of Pocock, The Machiavellian moment: see especially pp. 528-31. 